\title{
KAMPUNG HIJAU PRODUKTIF SEBAGAI PENERAPAN CORPORATE SOCIAL RESPONSIBILITY
}

\author{
Ompang Reski Hasibuan1, Eko Setyawan', Dewi Luqmania', Eka Setia Budi', Baling \\ Kustriyono2, Suyatno3, \& Totok R. Biyanto 4 \\ IPT. Pembangkitan Jawa Bali, UP Gresik \\ 2Fakultas Ekonomi dan Bisnis, Universitas Airlangga, Surabaya \\ ${ }^{3}$ Fakultas Ekonomi dan Bisnis, Universitas Pembangunan Nasional Veteran, Jakarta \\ 4Institut Teknologi Sepuluh November, Surabaya \\ E-mail: ompang.rizki@ptpjb.com
}

\begin{abstract}
ABSTRAK
Penelitian ini dilatarbelakangi oleh pembentukan aturan hukum mengenai Corporate Social Responsibility (CSR) pada tahun 2007. Penelitian ini bertujuan untuk membahas dampak positif penerapan CSR oleh perusahaan di Kramatinggil, Gresik, Jawa Timur. Subjek penelitian merupakan masyarakat yang mayoritas memiliki latar belakang pendidikan setingkat SMA. Metode yang digunakan dalam penelitian penerapan CSR ini adalah metode deskriptif kualitatif. Metode kualitatif dalam penelitian ini menggunakan pilihan pendekatan phenomenologik/fenomenologi. Pengolahan data dalam hal ini dilakukan dengan mengkategorikan catatan lapangan dari hasil depth interview. Pengolahan data juga dilakukan dari hasil data survey yang telah diolah kemudian dinarasikan dan dari hasil FGD (Focus Group Discussion) yang dilakukan bagi penerima manfaat. Hasil CSR perusahaan kepada masyarakat terbukti berhasil meningkatkan rasio kebun terhadap keseluruhan ruang yang digunakan dengan penerapan kebun vertikal dan Tanam Buah Dalam Pot (Tabulampot). Kegiatan tersebut menjukkan bahwa CSR perusahaan di daerah Kramatinggil terlah berhasil melestarikan sumber daya alam dan mensejahterakan penduduk sekitarnya.
\end{abstract}

Kata kunci: dampak positif, penerapan CSR, Kramatinggil

\begin{abstract}
This research background is the establishment of a legal rule regarding Corporate Social Responsibility (CSR) in 2007. This study aims to discuss the positive impact of CSR implementation by companies in Kramatinggil, Gresik, East Java. The research subjects are the people who are the majority have a high school education background. The method used in the study of the application of CSR is a qualitative descriptive method. The qualitative approach in this research uses a phenomenological. Data processing, in this case, is done by categorising field notes from the results of depth interviews. Data processing is also done from the effects of survey data that has been processed and then narrated and from the impact of FGD (Focus Group Discussion) conducted for beneficiaries. The result shows that the community have proven to be successful in increasing the ratio of gardens to the entire space used by the application of vertical gardens and Planting Fruits in Pot (Tabulampot). The activity showed that the company's CSR in the Kramatinggil area had succeeded in conserving natural resources and the welfare of the surrounding population.
\end{abstract}

Keywords: positive impact, implementation of CSR, kramatinggil 


\author{
Ompang Reski Hasibuan \\ Eko Setyawan \\ Dewi Luqmania \\ Eka Setia Budi \\ Baling Kustriyono \\ Suyatno \\ Totok R. Biyanto
}

\title{
PENDAHULUAN
}

Penerapan kegiatan green pada sebuah perusahaan harus memperhatikan kelestarian bumi, bukan hanya memperhatikan masalah kepatuhan kepada peraturan. Perusahaan harus memperhatikan harapan dan tuntutan masyarakat, pelanggan, pesaing, karyawan, dan pemegang saham. Praktek ramah lingkungan yang sering dianggap sulit dijangkau atau terlalu mahal, mendorong beberapa industri untuk melakukan apa yang diperlukan untuk memenuhi persyaratan hukum minimum. Namun, pola pikir ini sudah usang. Saat ini, telah diketahui bahwa praktik kegiatan green dan keuntungan ekonomi memiliki hubungan yang erat. Di perusahaan. Tim yang inovatif dan berpengetahuan teknis diperlukan untuk memanfaatkan peluang untuk mengaitkan profitabilitas dengan kegiatan kegiatan lingkungan.

Peningkatan seperti konsumsi energi dan pengurangan bahan baku, minimalisasi produksi limbah, dan maksimalisasi hasil produksi merupakan faktor yang sangat penting untuk meningkatkan ekonomi dan profitabilitas pabrik. Ada peluang besar bagi akademisi dan praktisi secara teknis dan inovatif untuk membawa pengetahuan dan keahlian mereka ke dalam praktik kegiatan green. Tiga pendorong utama untuk kegiatan green adalah kelestarian bumi, kesejahteraan manusia, dan keuntungan. Menetapkan sasaran green terkait dengan beberapa masalah lingkungan dan masyarakat sekitar, digabungkan dengan emisi, aliran limbah cair dan padat lainnya sebagai bagian dari kepentingan global (Nair, 2011). Green telah menjadi bagian penting dalam gloalisasi dunia saat ini.

Globalisasi telah menjadi topik yang diperbincangkan dalam ekonomi internasional (Mursitama \& Fakhrudin, 2014). Para pendukung mengklaim bahwa globalisasi berkontribusi untuk meningkatkan kesejahteraan dan mengurangi kemiskinan, sementara pendapat yang berlawanan mengatakan bahwa gloalisasi akan meningkatkan ketidakadilan global (Hallberger \& Malmberg, 2014). Perusahaan telah memperluas dan meningkatkan akses mereka terhadap sumber daya alam (SDA) serta tenaga kerja (SDM) murah yang sering terletak di daerah-daerah, dimana kemiskinan dan disfungsi sosial lainnya cukup besar. Kesenjangan dapat memaksa perusahaan ke dalam situasi di mana kepentingan saling berbenturan (Frostenson \& Helin, 2011). Peningkatan tekanan dari pemangku kepentingannya termasuk Lembaga Swadaya Masyarakat (LSM) (Blowfield \& Murray, 2014), membuat perusahaan menghadapi tanggung jawab yang lebih tinggi atas tindakan dan pengaruh mereka terhadap dunia sekitarnya (Jenkins \& Williamson, 2015). Masalah 
lingkungan, seperti perubahan iklim bersama dengan hak asasi manusia menjadi topik yang banyak dibahas dalam makalah ilmiah dan jurnal terkenal. Sasaran kegiatan CSR adalah daerah sekitar perusahaan yang mempunyai potensi untuk ikut disejaterakan; dalam hal ini perusahaan memilih daerah Kramatingil sebagai mitra CSR.

Sebagai daerah yang diapit oleh banyak industri besar, Kramatinggil memiliki masalah kota besar seperti kurangnya lahan, tingkat kepadatan penduduk tinggi, pengangguran dan kriminalitas. Tercatat dalam data desa pada tahun 2018, Kramatinggil memiliki ruang terbuka yang sangat rendah, yaitu hanya sekitar 0,68 Ha. Kondisi geografis tersebut berdampak pada peningkatan suhu udara dan karbondioksida karena kurangnya penyerapan dari tanaman. Tercatat dalam data kesehatan UPT Puskesmas Alun-Alun, kasus penyakit terbanyak yang terjadi adalah gangguan pernapasan (Pharingitis) yang mencapai 12.322 kasus di tahun 2018 di seluruh wilayah kecamatan Gresik. Lingkungan desa Kramatinggil tergolong rawan karena berada di ring I daerah operasi beberapa perusahaan besar. Program penghijauan dan pengelolaan lingkungan telah menjadi fokus kegiatan CSR UP Gresik di Desa Kramatinggil yang telah terintegrasi menjadi program Kampung Hijau Poduktif. Makalah ini akan menyajikan pengaruh CSR terhadap kinerja internal perusahaan, masyarakat sekitar perusahaan dan klestarian lingkungan.

Manfaat teoritis penelitian ini adalah dapat menjadi acuan dalam mengukur kesesuaian program dengan indikator capaian program yang telah dirumuskan sebelumnya dalam perencanaan tahunan dari beberapa aspek. Selain itu juga mengukur dampak yang ditimbulkan oleh pergerakan ekonomi bagi masyarakat penerima program-program CSR atau yang dinamakan dengan multiplier effect. Dari sisi praktis, penelitian dapat menjadi pedoman bagi Community Development Officer (CDO) dalam kegiatan monitoring dan evaluasi program yang dilaksanakan untuk menjawab kebutuhan masyarakat. Hal ini akan membantu CDO dalam menjustifikasi apakah program yang telah berjalan benar-benar mampu menjawab kebutuhan masyarakat dan manfaatnya benar-benar dirasakan oleh masyarakat, ataukah masih perlu perbaikan juga pengembangan di dalamnya.

\section{TINJAUAN PUSTAKA}

\section{Corporate Social Responsibility}

Untuk meningkatkan kinerja ekonomi dan mempertahankan reputasi perusahaan, banyak perusahaan mencari strategi manajemen baru untuk membedakan dan mendapatkan keunggulan kompetitif terhadap perusahaan pesaing lainnya (Benjamin \& Rebecca, 2011). CSR (Hallberger \& Malmberg, 2014) disebut dalam berbagai literatur sebagai tanggung jawab perusahaan, tanggung jawab bisnis, tanggung jawab perusahaan terhadap warga negara, keberlanjutan perusahaan, dan sebagainya Blowfield \& Murray, 2014). Pendapat 


\section{Ompang Reski Hasibuan \\ Eko Setyawan \\ Dewi Luqmania \\ Eka Setia Budi \\ Baling Kustriyono \\ Suyatno \\ Totok R. Biyanto}

lain mengatakan bahwa CSR mengacu pada tanggung jawab perusahaan untuk berinteraksi dengan masyarakatnya dan meningkatkan kesejahteraan keseluruhan (Grafström et al., 2008). Selama dekade terakhir CSR telah menjadi salah satu masalah terpenting bagi organisasi nasional (Frederic \& Martha, 2012) antara pemangku kepentingan perusahaan dengan LSM. LSM mempunyai misi untuk mengincar perusahaan yang mengabaikan aturan tertentu, seperti menggunakan pekerja anak dan melanggar hukum lingkungan (Frostenson \& Helin, 2011).

Diskusi tentang CSR muncul pada tahun 1953 ketika Howard Botton dalam bukunya yang berjudul "Tanggung jawab sosial pengusaha" menjelaskan jenis tanggung jawab sosial yang dapat diharapkan dari sebuah perusahaan (Spitzeck \& Hansen, 2010). Terdapat dua pendapat mengenai CSR. Satu pihak menganggap bahwa CSR harus bersifat wajib untuk masing-masing perusahaan, sementara pihak lain mengklaim bahwa CSR bersifat tidak wajib dan pelaksanaannya terserah masing-masing perusahaan untuk memutuskan apakah mereka mematuhi CSR atau tidak. Pendapat pertama didukung oleh Milton Friedman yang menyatakan bahwa satu-satunya tanggung jawab yang dimiliki perusahaan terhadap para pemangku kepentingannya adalah untuk menghasilkan maksimalisasi keuntungan (Frostenson \& Helin, 2011).

Saat ini masih terdapat banyak kontradiksi mengenai CSR dan kinerja keuangan (Pedersen, 2006). Namun, terdapat banyak pendukung yang percaya bahwa CSR dapat menjadi faktor penting untuk kelangsungan hidup perusahaan jangka panjang dan strategi manajemen yang penting untuk memuaskan para pemangku kepentingannya (Frostenson \& Helin, 2011).

Karena kenyataan ini, prestasi perusahaan harus mempertimbangkan efek utama CSR ini di seluruh dunia. Perusahaan yang menggunakan CSR sebagai salah satu strategi mereka akan mampu untuk menciptakan lebih banyak peluang bisnis, yang dengan demikian perusahaan mendapatkan keunggulan kompetitif dari perusahaan lainnya (Arendt \& Brettel, 2010). Pada Juli 2007 Indonesia adalah negara pertama yang mengumumkan undang-undang wajib tentang CSR, yang berlaku untuk perusahaan yang menggunakan sumber daya alam (Marko \& Stephanie, 2014). 


\section{METODE PENELITIAN}

Kajian ini dilakukan terhadap perusahaan yang mengunakan sumber daya alam di dekat desa Kramatinggil. Beberapa program dalam hal kelestarian alam, kesejahteraan manusia dan keuntungan telah dilakukan dan diamati keberhasilannya. Penerapan CSR dalam kajian ini mempunyai beberapa variabel input yaitu peningkatan pengunaan lahan, pengunaan dan pemanfaatan kembali sampah, peningkatan kesadaran masyarakat, yang akan dihubungkan dengan efek ekonomi dan sosial masyarakat penerim CSR.

Penelitian merupakan penelitian deskriptif dengan metode kualitatif. Metode kualitatif dalam penelitian ini menggunakan pilihan pendekatan phenomenologik/ fenomenologi. Pendekatan fenomenologi yang berakar dari paradigma konstruktivisme yang bersifat interpretif. Secara ontologis, paradigma ini melihat realitas sebagai sesuatu yang bersifat relatif, yaitu sesuai dengan konteks spesifik yang dinilai relevan oleh para aktor sosial. Pada penelitian ini karakteristik dan proporsi subjek penelitian berdasar data desa per Maret 2018 tercatat tingkat pendidikan rata-rata masyarakat Desa Kramatinggil adalah tingkat SMA yaitu sebesar 987 orang. Kemudian disusul lulusan SD 412 orang dan SMP 412 orang. Sedangkan lulusan sarjana sebanyak 151 orang.

Tabel 1. menunjukkan kelompok umur usia produktif yaitu 15-64 tahun lebih banyak dibanding usia non produktif. Sebanyak 2864 total jumlah penduduk Desa Kramatinggil, 1961 diantaranya adalah kelompok usia produktif. Berdasarkan perhitungan rasio ketergantungan (dependency ratio) atau angka beban ketergantungan, setiap 100 orang usia produktif di Desa Kramatinggil menanggung beban 6 orang penduduk kategori usia non produktif. Hal ini menunjukkan bahwa usia produktif lebih banyak dibandingkan dengan usia non produktif. Sebagian besar penduduk Desa Kramatinggil bekerja di sebagai karyawan swasta. Kemudian urutan kedua bekeja sebagai wiraswasta.

Tabel 1.

Kelompok umur masyarakat Desa Kramatinggil

\begin{tabular}{lccc}
\hline \multirow{2}{*}{ Kelompok Usia } & \multicolumn{3}{c}{ Data Per Maret } \\
\cline { 2 - 4 } & Laki-laki & Perempuan & Jumlah \\
\hline Non Produktif (0-14) & 306 & 314 & 620 \\
Produktif (15-64) & 903 & 1030 & 1961 \\
Non Produktif (>64) & 50 & 53 & 103 \\
\hline
\end{tabular}

Monitoring dan evaluasi penelitian ini bersumber dari penerima manfaat program (beneficiaries). Data penelitian ini berasal dari satu sumber yang diperkaya dengan sumber- 


\section{Ompang Reski Hasibuan \\ Eko Setyawan \\ Dewi Luqmania \\ Eka Setia Budi \\ Baling Kustriyono \\ Suyatno \\ Totok R. Biyanto}

sumber lain yang direkomendasikan oleh sumber terdahulu dan relevan dengan jenis data yang dibutuhkan. Teknik pengambilan sampel ini disebut dengan snowball sampling. Jumlah informan untuk masing-masing kelompok tidak didasarkan ukuran kuantitatif melainkan kecukupan informasi yang ditandai dengan adanya pengulangan informasi-informasi di antara para informan.

Kegiatan penelitian ini melibatkan masyarakat sehingga proses CSR menjadi utuh. Masyarakat terlibat dalam keseluruhan proses mulai dari perencanaan hingga evaluasi (evaluasi partisipatif). Partisipan penelitian adalah masyarakat sebagai penerima manfaat, tokoh masyarakat, civil society organization, pihak perusahaan, dan pemerintah.

Pengolahan data dilakukan dengan mengelompokan/mengklasifikasiikan data. Pengklasifikasian ini dilakukan dengan membuat catatan lapangan dari hasil wawancara. Hal ini dimaksudkan untuk mengkategorikan pendapat-pendapat yang ada di masyarakat sesuai dengan kerangka fikir yang digunakan. Selain pengkategorian catatan lapangan dari hasil depth interview, pengolahan data juga dilakukan dari hasil data survey yang telah diolah kemudian dinarasikan. Pengolahan data juga dilakukan dari hasil FGD (Focus Group Discussion) yang dilakukan bagi penerima manfaat.

Reduksi data dilakukan dengan pemilahan data yang terkumpul dalam catatan lapangan ke dalam penggolongan data, untuk menentukan bagian-bagian yang akan dibuang, mempertajam, dan mengembangkan. Data yang direduksi agar memperoleh gambaran yang lebih tajam dan menjaga peneliti untuk tetap fokus pada data yang dibutuhkan dan membuang yang tidak dibutuhkan. Setelah data direduksi, maka langkah selanjutnya adalah menyajikan data. Melalui penyajian data, maka data terorganisasikan, tersusun dalam pola hubungan, sehingga akan semakin mudah dipahami. Langkah berikutnya adalah penarikan kesimpulan dan verifikasi.

\section{HASIL DAN DISKUSI}

Beberapa program CSR telah dilakukan oleh perusahaan sebagai wujud kepedulian terhadap kesejahteraan manusia dan kelestarian alam sekitar. Analisa dampak program CSR bagi manusia dan alam sekitar perlu dilakukan untuk melihat kinerja program ini dan sekaligus memberikan sumbangsih kepada ilmu pengetahuan. Hasil dari CSR akan dipaparkan dalam beberapa poin berikut: 


\section{Integrasi Program Lingkungan "Kampung Hijau Produktif"}

Tujuan dari program ini adalah untuk meningkatkan kesejahteraan masyarakat melalui pemenuhan kebutuhan hidup dasar, menciptakan lingkungan hidup yang nyaman dan sehat, dengan cara memaksimalkan penggunaan lahan terbatas yang saat ini telah tergantikan oleh rumah dan bangunan lainnya. Ketentuan agar daerah memiliki 30 persen Rauang Tebuka Hijau (RTH) sudah diatur sejak 2007 melalui Undang-Undang (UU) Nomor 26 Tahun 2007 tentang Penataan Ruang.

CSR yang unik telah dilakukan oleh perusahaan yaitu dengan gotong royong dalam penghijauan dengan masyarakat setempat. Keterlibatan masyarakat dalam program penghijauan ini dapat meningkatkan tingkat keberhasilan program, dapat menyesuaikan jenis tanaman yang berguna bagi masyaarakat, menekan biaya dan menumbuhkan semangat rasa memiliki bersama dan persatuan.

Program penghijauan produktif ini sejalan dengan tujuan pembangunan berkelanjutan, khususnya untuk mengurangi kemiskinan masyarakat, melestarikan planet bumi dan kesejahteran masyarakat dalam arti yang lebih luas. Program ini memiliki 169 target untuk 17 tujuan. "Program Kampung Hijau Produktif" ini telah mampu mencapai tujuan nomor 11 yang lebih luas yaitu "Sustainable Cities and Communities". Upaya ini dilakukan untuk mewujudkan ketahanan terhadap bencana melalui pengembangan dan penerapan green air, green waste (mengelola limbah dan menguranginya melalui daur ulang), dan green transportation.

Masyarakat Kramatinggil telah menanam lebih dari 2.218 tanaman yang ditanam di dalam pot (Tabulampot), dikarenakan memang tidak ada lahan terbuka yang bisa ditanami langsung. Kinerja program penghijauan ditampilkan dalam Diagram 1.

Potensi serapan karbon dari 1500 pohon buah yang ditanam dalam pot (tabulam pot) menghasilkan 89.042,3 Kg/Tahun. Peningkatan lahan tutupan hijau meningkat dari tahun 2017 yaitu 1,99 Ha hingga 2,05 Ha di tahun 2018. Area tutupan hijau tersebut menghasilkan oksigen sebanyak $765,6 \mathrm{Kg} / \mathrm{hari}$ dan berhasil menurunkan suhu sebesar 0,04 derajat Celsius.

Dengan adanya penghijauan terpadu, Kramatinggil telah mampu menyelesaikan masalahmasalah lingkungan seperti meningkatnya kualitas udara, menurunnya polusi air, dan penurunan suhu udara. Selain itu, Kampung Hijau Produktif adalah program terpadu yang berfokus pada gerakan lingkungan dan pemberdayaan masyarakat. Kegiatan yang telah dilakukan di Kramatinggil terdiri dari: upaya menjaga kebersihan lingkungan, pengelolaan sampah melalui bank sampah, mendaur ulang sampah plastik menjadi kerajinan, 


\section{Ompang Reski Hasibuan \\ Eko Setyawan \\ Dewi Luqmania \\ Eka Setia Budi \\ Baling Kustriyono \\ Suyatno \\ Totok R. Biyanto}

pemasangan pengelolaan air limbah komunal dan pengomposan sampah rumah tangga selain meningkatkan ruang terbuka hijau dengan menanam tanaman produktif (buah dan sayuran) dalam pot dan kebun vertikal.

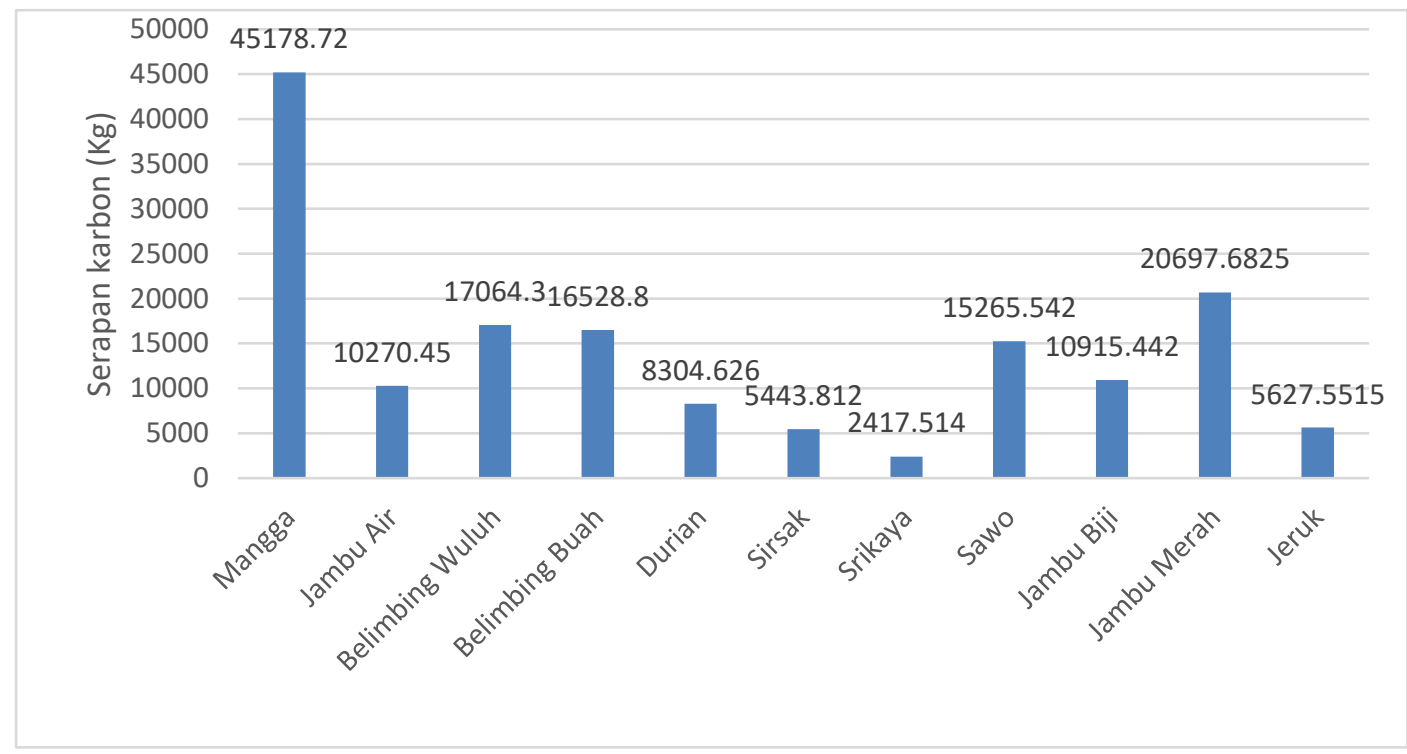

\section{Diagram 1.}

Potensi Serapan Karbon Tabulampot (Kg) hasil penghijauan

Program bank sampah, pada tahun 2018, telah diintegrasikan dan diluncurkan menjadi Kramatinggil Kampung Hijau Produktif yang memiliki visi menjadi desa ekowisata yang produktif, kreatif dan hijau, dengan misi sebagai berikut:

- mengembangkan desa hijau dan layak huni,

- mengembangkan kualitas social masyarakat yang guyub,

- program yang mampu meningkatkan produktivitas dan kesejahteraan masyarakat Kramatinggil secara finansial.

Saat ini program tersebut telah terdapat 33 kader lingkungan yang menjalankan program Bank Sampah di Kramatinggil dengan prosedure terlihat pada Bagan 1. Kader lingkungan tersebut mampu membina dan meningkatkan keterampilan masyarakat lainnya. Program bank sampah, yang diikuti oleh semua warga Kramatinggil telah melalui proses panjang untuk dapat meningkatkan partisipasi semua masyarakat. Jumlah penerima manfaat program ini selama program berlangsung tertera pada Tabel 2. 


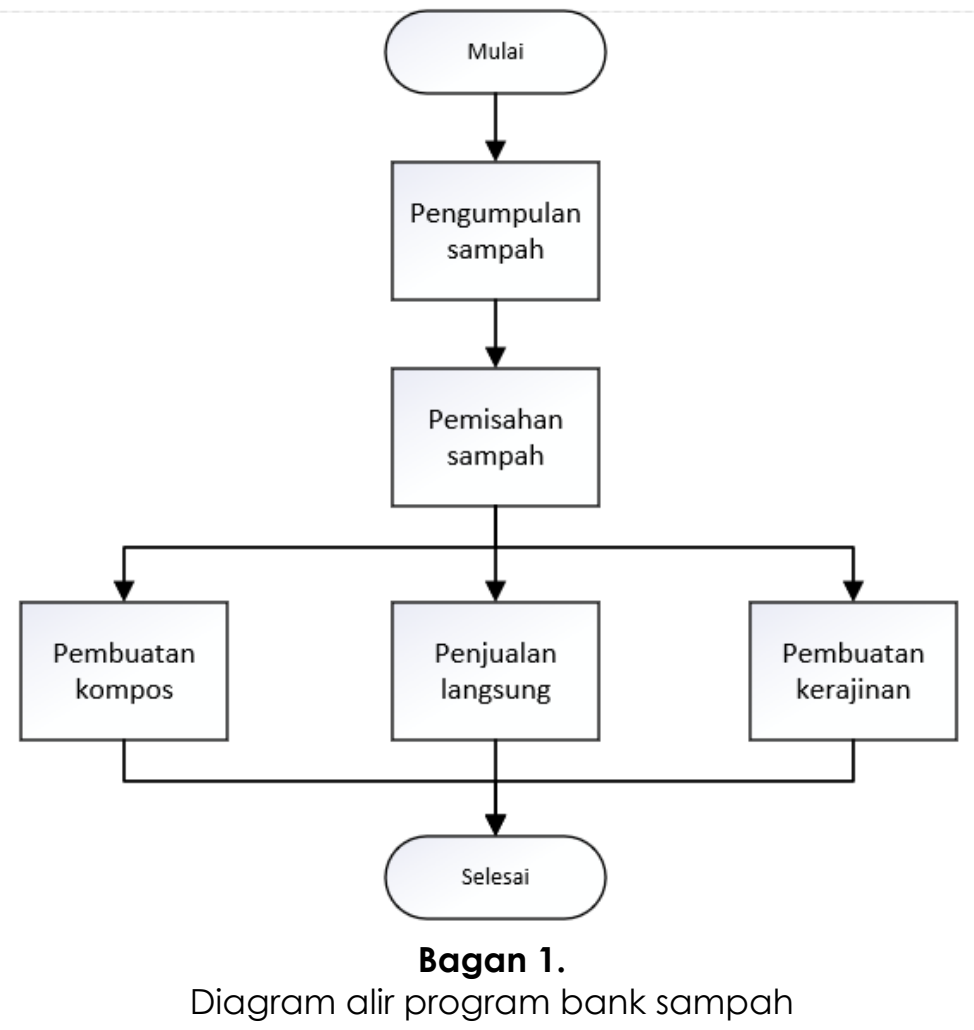

Sebanyak 358 penduduk merupakan nasabah bank Sampah dengan rasio $22 \%$ pria dan $78 \%$ wanita. Pengembangan bank sampah terus dilakukan hingga 15 unit bank sampah seluruh RT di Kramatinggil. Keunikan bank sampah di Kramatinggil adalah karena penerapan program "Kantong Pemberdayaan", dimana pendapatan atau tabungan yang diperoleh dari Bank Sampah telah mampu memenuhi pembiayaan operasional rukun tetangga.

Tabel 2.

Jumlah penerima manfaat program bank sampah Kramatinggil tahun 2014-2018

\begin{tabular}{cc}
\hline Tahun Program & Jumlah Penerima Manfaat \\
\hline 2014 & 65 orang \\
2015 & 74 orang \\
2016 & 313 orang \\
2017 & 756 orang \\
2018 & 1556 orang \\
\hline
\end{tabular}

Kuantitas sampah yang dapat didonasikan dari bank sampah selama program ini berlangsung tergantung dari banyaknya sampah yang tersedia. Ketersediaan sampah sangat tergantung dari aktifitas perusahaan seperti terlihat pada Tabel 3 . Tabel 4 menunjukkan adanya pengaruh program ini terhadap kinerja internal perusahaan, dimana jumlah sampah menunjukkan semakin berkurang dibandingkan kondisi awal tanpa adanya program. 
Tabel 3.

Rekapitulasi volume sampah tahun 2014-2018

\begin{tabular}{ccc}
\hline No & Tahun & Volume Sampah $(\mathbf{k g})$ \\
\hline 1 & 2014 & $37.161,2$ \\
2 & 2015 & $44.042,0$ \\
3 & 2016 & $40.356,6$ \\
4 & 2017 & $5.716,6$ \\
5 & 2018 & $10.954,8$ \\
\hline \multicolumn{2}{c}{ Total } & $138.231,2$ \\
\hline
\end{tabular}

Perilaku dan kesejahteraan masyarakat perlu dipantau, karena merupakan sasaran utama CSR. Selama program berlangsung, terdapat perubahan perilaku di masyarakat yang meliputi:

\section{Tingkat Partisipasi Masyarakat Terus Meningkat}

Kramatinggil, sebagai desa padat penduduk memiliki karakter yang berbeda. Awalnya hanya sedikit masyarakat yang berpartisipasi. Mereka yang tidak mau berpartisipasi beralasan kegiatan ini akan memakan waktu dan membutuhkan banyak perawatan. Namun setelah melihat perubahan desa mereka yang menjadi bersih, hijau dan teduh, banyak masyarakat yang sebelumnya enggan menanam, mulai ikut melakukan penghijauan di halaman rumah mereka dalam pot, bahkan 4 dari 5 orang difabel telah berpartisipasi dalam kegiatan penghijauan.

\section{Menumbuhkan Budaya Memilah Sampah dan Memanfaatkan Sampah}

Kebiasaan yang muncul di masyarakat adalah proses memilah sampah antara jenis sampah organik dan anorganik. Di masa lalu, berbagai sampah organik dan anorganik dibuang ke TPA tanpa ada upaya pemilahan dan pengolahan mandiri. Saat itu kesadaran masyarakat akan potensi sampah belum terbangun. Melalui program Bank Sampah, masyarakat mulai melihat ternyata ada manfaat yang bisa diambil dari sampah.

\section{Inovasi}

Indikator CSR bisa diterima dan berjalan dengan baik karena adanya partisipasi aktif dari masyarakat, bukan hanya partisipasi yang telah dicapai dari program CSR perusahaan ini. Beberapa inovasi telah dikembangkan oleh masyarakat itu sendiri. Beberapa inovasi yang telah dilakukan masyarakat adalah: 


\section{Instalasi Pengelolaan Air Limbah (IPAL)}

Instalasi Pengelolaan Air Limbah didirikan untuk mengolah air limbah melalui proses penyaringan tertentu. Di setiap unit IPAL dapat menghasilkan $30.000 \mathrm{ml}$ air yang layak digunakan untuk penyiraman 80 tanaman dan menghemat penggunaan air bersih sebanyak $36 \%$.

\section{Instalasi Vertical Shower}

Vertical Shower ini memudahkan penyiraman vertical garden di Kramatinggil. Sistem Vertical Shower mampu menghemat tenaga penyiraman manual, waktu dan juga air karena air akan langsung menyirami tanaman dari pipa yang dipasang di atas rangka kebun langsung ke bawah tanaman. Sistem pancuran ini dapat menghemat penggunaan air hingga tiga kali lipat.

\section{Kantong Pemberdayaan}

Program Bank Sampah di Kramatinggil mampu memberi kebermanfaatan yang berbeda dengan bank sampah lainnya. Pendapatan yang diperoleh dari Bank Sampah mampu membantu keuangan operasional Desa Kramatinggil dan mengurangi biaya sekolah.

\section{SIMPULAN}

CSR sebagai wujud kepedulian perusahaan perusahaan kepada masyarakat di Kabupaten Gresik pada umumnya dan desa Kramatinggil pada khususnya terlah terbukti berhasil, dengan meningkatkan rasio kebun terhadap keseluruhan ruang yang digunakan. Penghijauan dengan kebun vertikal dan Tabulampot menghasilkan ketahanan pangan meningkat, udara semakin bersih, air semakin lestari dan pendapatan masyarakat meningkat. Program ini bukan hanya dapat meningkatkan kesadaran dan keterlibatan masyarakat, tetapi juga dapat meningkatkan inovasi dari CSR. Inovasi tersebut telah dilalakukan sendiri oleh masyarakat dengan membuat bank sampah, pengolahan air dan sistem penyiraman vertikal yang lebih efektif. Pengaruh program ini terhadap kinerja internal perusahaan dapat dilihat dari jumlah sampah yang semakin berkurang dibandingkan kondisi awal tanpa adanya program.

\section{PERSEMBAHAN}

Para penulis mengucapkan banyak berterima kasih kepada PT. PJB UP Gresik yang telah memfasilitasi penelitian ini. 


\section{Ompang Reski Hasibuan \\ Eko Setyawan \\ Dewi Luqmania \\ Eka Setia Budi \\ Baling Kustriyono \\ Suyatno \\ Totok R. Biyanto \\ DAFTAR PUSTAKA}

Arendt, S., and Brettel, M. 2010. Understanding the influence of corporate social responsibility on corporate identity, image, and firm performance. Management Decision 48(10): 1469-1492.

Benjamin J. H. O., and Rebecca, O. 2011. Defining the Role Engagement of the Human, Resources Professionals. The Special Issue on Contemporary Issues in Business and Economics 2 (5).

Blowfield, M., and Murray, A. 2014. Corporate Responsibility. Oxford University Press.

Frederic M., and Martha, R. 2012. The worldwide diffusion of the global reporting initiative: what is the point? . Journal of Cleaner Production 33: 132-144.

Frostenson, M., and Helin, S. 2011. Organising Corporate Responsibility Communication Through Filtration: A Study of Web. Journal of Business Ethics 100 (1): 31-43.

Grafström, M., Windell K., and Göthberg, P. 2015. CSR: Företagsansvar i förändring. Liber.

Hallberger, P. M. A. 2014. How Corporate Social Responsibility affect brand image - A qualitative study. Linnaeus University. School of Business and Economics, Department of Marketing.

Jenkins, W. W. D. 2015. Strategic Management and Business Analysis. Taylor \& Franchise Group.

Marko, H., and Stephanie, M. 2014. Profitability and Corporate Social Responsibility: An Analysis of Indonesia's Listed Company. Asia Pacific Journal of Accounting and Finance 3 (1).

Mursitama, T. N., and Fakhrudin, M. 2014 Evolving practices of corporate social responsibility in Indonesia's pulp and paper industry Asian J. Sci. 7 (1): 1-17.

Nair, Sukumaran. 2011. "What are the strategies for sustainable chemical production". Hydrocarbon Proc: January (69-77).

Pederse, E. R. 2010 Modelling CSR: How Managers Understand the Responsibilities of Business Towards Society, Journal of Business Ethics 91 (2): 155-166.

Spitzeck, H., and Hansen, E. 2010. Stakeholder governance: how stakeholders influence corporate decision making, Corporate Governance 10(4): 378-391. 